\title{
Targeting Intergovernmental Aid to Local Schools: An Analysis of Federal and State Efforts
}

John P. Pelissero

Loyola University Chicago, jpeliss@luc.edu

David R. Morgan

University of Oklahoma

Follow this and additional works at: https://ecommons.luc.edu/politicalscience_facpubs

Part of the Political Science Commons

\section{Recommended Citation}

Pelissero, John P. and David R. Morgan, "Targeting Intergovernmental Aid to Local Schools: An Analysis of Federal and State Efforts," Western Political Quarterly 45 (December 1992): 985-99.

This Article is brought to you for free and open access by the Faculty Publications and Other Works by Department at Loyola eCommons. It has been accepted for inclusion in Political Science: Faculty Publications and Other Works by an authorized administrator of Loyola eCommons. For more information, please contact ecommons@luc.edu. (c) (1) $\Theta$

This work is licensed under a Creative Commons Attribution-Noncommercial-No Derivative Works 3.0 License. 


\title{
TARGETING INTERGOVERNMENTAL AID TO LOCAL SCHOOLS: AN ANALYSIS OF FEDERAL AND STATE EFFORTS
}

\author{
John P. Pelissero, Loyola University Chicago \\ and \\ David R. Morgan, University of Oklahoma
}

tudents of public policy have long been interested in redistribu-
tion. Especially in a political system permitting some degree of
decentralization, the question often becomes which level of government should assist the poor (Ladd and Doolittle 1982). Economic theory favors the national government, with its broader geographic scope and more progressive tax system. Yet many argue that the states are closer to local problems and thus best suited to reallocate financial resources. Although a growing body of research has begun to address this issue (see, for example, Dye and Hurley 1978; Rafter 1985; Stephens and Olson 1981; Ward 1981), very little appears comparing the relative targeting effectiveness of the national government and the states in the area of aid to local public schools. The purpose here is to help fill this research gap by comparing state and federal targeting of intergovernmental assistance to a large number of local school districts across the United States.

We begin by considering the theoretical issues surrounding redistribution or targeting. ${ }^{1}$ Then we briefly review some of the empirical findings that compare federal and state targeting. The analysis proceeds in several stages. First, we examine the extent to which

Received: December 12, 1990

Accepted for Publication: December 12, 1992

NotE: An earlier version of this paper was presented at the 1989 Annual Meeting of the American Political Science Association, Atlanta, Georgia, August 31-September 3, 1989. We gratefully acknowledge the assistance of the Small Research Grant Program, Office of Research Services, Loyola University of Chicago for data acquisition. Our thanks to Geri Rowden of the University of Oklahoma for typing assistance.

${ }^{1}$ Strictly speaking, redistribution and targeting are not synonymous, although they obviously are closely related. Redistribution requires a Robin Hood effect; targeting, on the other hand, says nothing about the source of the funds that are to be allocated on the basis of need. In effect, targeting is a necessary but not sufficient condition for redistribution. Yet, we think the two terms are similar enough to justify using them synonymously. 
intergovernmental aid is enrollment-driven. Second, we examine the results of an analysis of enrollment influences in individual states. The findings from this exercise lead to the final step, an examination of the concentration on socioeconomic and fiscal needs in a subset of bettertargeting states.

\section{Federal versus State Targeting of Grants-In-Aid}

The issue of who should help needy local schools might be seen as part of a larger debate over the appropriate division of responsibilities within the U.S. federal system. According to considerable economic and political theory, the national government is better positioned to pursue redistributive policies than state and local governments. Presumably, the central government, with its inclusive geographic scope, can undertake redistributive policies with less risk than can state or local jurisdictions (see Oates 1972: ch. 1). Localities have special difficulties in dealing with economic and social conditions that sprawl across jurisdictional boundaries. So Peterson (1981: 68-71) urges local governments to eschew redistributive efforts and instead to adopt policies that will enhance the economic base and productive potential of the community. Otherwise, the permeability of local government boundaries and mobility of capital leaves these units unduly vulnerable to loss of mobile citizenry who generally belong to the revenue-producing segment of the population (David and Kantor 1983: 293). The central government thus inherits the responsibility for redistribution almost by default.

Despite the theoretical argument for federal targeting, other literature offers two notable reasons why the national government may do poorly at redistribution. First is what Downs (1980: 530) calls the "law of political dispersion." In a democratic system based on single-member districts, politicians must spread the benefits of public policy to construct and maintain governing coalitions and to ensure reelection. The compulsion to disperse benefits widely, often referred to as universalism, tends to make all jurisdictions eligible for grant programs, reducing if not eliminating any potential for targeting. Second, Congress's commitment to a wide dispersal of benefits has been facilitated, at least until recently, by the absence of effective budgetary constraints (Stein and Hamm 1987).

Research on the targeting of federal funds yields a mixed picture. Despite the theoretical rationale for redistribution, most federal grants 
are driven by population not local need (Copeland and Meier 1984). There are exceptions, of course. Project grants leave some discretion in the hands of federal administrators, which may allow concentration of funds on needy people or needy areas (Anagnoson 1980: 235). And, certain substantive programs seem more amenable to targeting than others. The now defunct Urban Development Action Grants did a relatively good job of targeting funds on the most distressed communities (Rich 1982). Studies by the U.S. General Accounting Office (1990) also show that federal revenue sharing reduced local fiscal disparities more than did state aid programs. Under certain conditions, then, federal programs may achieve some modest degree of targeting.

In the field of public education, where its financial support has been minimal, the federal government has been able to offer funding packages with fairly limited purposes. Thus a number of federal categorical grants have been aimed at special groups. Of these, the largest has been Chapter I (formerly Title 1) of the Elementary and Secondary Education Act of 1965, which funds compensatory education for children from low-income families (Tsang and Levin 1983: 352). Timpane (1978: 2) estimated that about 56 percent of federal expenditures for elementary and secondary schools for 1976 were for programs targeted to disadvantaged groups. But, a number of federal formula-based education grants do not target on the basis of social, economic, or fiscal hardship, e.g., grants for vocational and technical training and for educating the handicapped. So federal aid to education is not purely redistributive either by intent or practice.

What does research show regarding targeting by the states? Perhaps state policymakers, being closer to local problems, may be more responsive to local needs. Warren (1981: 31) also suggests that communities within a given state are more homogeneous than localities scattered across the nation, thus making it easier for state policymakers to design need-based formulas to guide aid allocation decisions. Some studies do show that states target their aid to local governments and may do so more effectively than the federal government (Dye and Hurley 1978; Stephens and Olson 1981). For example, pooled analyses of the states have shown them to provide somewhat greater aid to cities with more social, economic, or fiscal need (Pelissero 1984, 1985; Stein 1981). But perhaps education is different. Even though state school formulas are closely tied to district enrollments, states have a long history of attempts to increase targeting to districts of special need. Still, states have a long history of attempts to reduce inequities 
in school funding. The results have been mixed, even though during the $1970 \mathrm{~s}, 28$ states modified their funding formulas to weaken the traditional nexus between dollars and pupils and to provide more money for the disadvantaged (Fuhrman 1982). So some states apparently do respond to school district need (Morgan and Pelissero 1989; Pelissero and Morgan 1987). Most of the research on state aid, however, does not offer separate analyses within individual states (an exception is Stein and Hamm 1987). Thus, the degree of targeting observed on the part of all states might be largely the result of the redistributive actions of just a few.

A final qualification: we must acknowledge that some federal or state programs may be more likely than others to reach districts with special requirements. But with an analysis of all districts in all states, it is not possible to disaggregate aid totals.

\section{Research Design}

Based on the above theory, our research expectations are as follows:

1. Enrollment will be the main determinant of both state and federal aid to independent school districts but will be an especially powerful force for states.

2. Federal aid per pupil will be better targeted to disadvantaged districts than will state aid.

3. State targeting will be a feature of aid systems in only a small number of states.

The analysis includes virtually the universe of U.S. independent school districts. Forty-five states have independent school districts; the parent government provides nearly all local school support in Hawaii, while Alaska, Maryland, North Carolina, and Virginia have no independent school districts (U.S. Bureau of the Census 1983: 17). Also, the analysis will exclude Rhode Island, with only three independent school districts. The final number of districts included in the study was 13,655 (higher education districts were excluded). We chose the period 1982 because of the availability of a Census of Governments report in that year and its close proximity to the collection of targeting indicators during the 1980 census. The 1982 data also provide the opportunity to examine the effects of state targeting that were an expected consequence of the educational finance reforms put in place by a number of states during the 1970 s. 
The dependent variables for our study are federal aid (aggregate and per pupil) and state aid (aggregate and per pupil) to independent school districts in 1982.2 These data are from the 1982 Census of Governments. ${ }^{3}$ The choices for independent variables are modeled after the Stein and Hamm (1987) study of the universe of U.S. municipal governments. We first employ enrollment itself as a variable in an aggregate analysis of both federal and state aid in 1982. This allows us to examine initially the linkage between total intergovernmental aid from the federal or state governments and the number of pupils in the systems. The indicators of targeting are drawn from the 1980 census (by school district) and the Census of Governments. Three measures of need tap different aspects of socioeconomic problems in the school districts. Like Stein and Hamm (1987), we will use a district's per capita income as a predictor of aid. But we have added two key social targeting measures to the analysis: the proportion of the school district that is black and the percentage of indigent families with children in the school district. ${ }^{4}$ The two remaining targeting measures are indicators of the independent school districts' fiscal health. A fiscal effort measure has been constructed by taking a school district's total revenue from own sources (exclusive of tuition and fees) and dividing it by enrollment. The second fiscal variable taps the debt burden of the school district. We operationalize debt as the amount of annual debt interest divided by enrollment, or debt (interest) per pupil for each school district. If targeting occurs, we expect federal or state aid per pupil to be positively related to the proportion of black and poor families in the district and to the size of the debt burden. Further, we expect welltargeted systems to show a negative relationship between aid and both per capita income and revenue per pupil.

\section{FINDINGS}

We consider the effects of federal aid first. Table 1 presents two models of federal aid to over 13,000 independent school districts for

${ }^{2}$ Some nominally state funds actually represent federal pass-through aid. The Advisory Commission on Intergovernmental Relations (1980: 9) reports that net federal assistance (including pass-through) is about 17 percent of total intergovernmental aid to local education (for 1977). The national government directly supplies less than 2 percent of local school funding (U.S. Bureau of the Census 1990: 7). The data available for this research include only direct federal aid.

${ }^{3}$ These data were provided by Robert M. Stein, Rice University.

${ }^{4}$ Data on each of these socioeconomic measures are drawn from the 1980 Census, by school district, as reported by the National Center for Education Statistics. 
fiscal year 1982. The first equation, column 1, shows how much district enrollment alone affects total dollars of federal aid. Enrollment has a very strong and significant impact on federal aid, reflected in the beta of .62. In this equation, 38 percent of total federal aid can be explained by enrollment alone. In a subsequent model (not shown) we included the other need variables in the equation but they contributed virtually nothing to explained variance, as the adjusted $\mathrm{R}^{2}$ remained at .38. Because the need measures do not register in this assessment of total aid, it might be useful to transform the dependent variable. The aid literature reveals some disagreement over this issue, however. The most common approach is to use per capita figures, primarily to avoid what Dye and Hurley (1981) call the "so what" effect, that large jurisdictions receive the most money. Several studies take a different view, that an analysis using per capita figures may produce misleading results (Ward 1981), or that decision makers are more likely to think of total dollars rather than in per capita terms (Anton, Cawley, and Kramer, 1980: 104). The position one takes depends primarily on what the researcher wishes to show. We elect to use per pupil measures in most of this analysis because the results, especially with the state aid equations, are more interpretable and intuitively pleasing. We should note, however, that enrollment was tried as a predictor of federal per pupil aid but could account for none of the variation in this measure and is not used in the analysis shown in column 2 of Table 1.5

Column 2 offers a model of federal aid per pupil that includes the key measures of socioeconomic and fiscal need. ${ }^{6}$ Again, we expect that federal aid per pupil will be positively related to the proportion of blacks and poor children and size of district debt, and negatively related to per capita income and district own source revenues. This model of federal aid per pupil is quite weak, however. Only two predictors are significant and in the expected direction. Specifically, federal aid is very modestly targeted to school districts with larger proportions of children from poverty families (beta $=.11$ ) and lower per

\footnotetext{
${ }^{5}$ We also examined a model of total federal (and, in a later analysis, state) aid using aggregate need measures, but the level of intercorrelation between predictors was too high to use these as a comparison to the per pupil results reported here.

${ }^{6}$ It may be worth noting that the simple correlations between total enrollment and the social need measures were: total number of blacks in district, $r=.82$, total number of poor families with children, $r=.92$. The multicollinearity between these measures and enrollment was another reason not to include enrollment in the equation.
} 
TABLE 1

Federal and State Aid to Independent School Districts, Alternative REGRESSION MODELS, 1982

\begin{tabular}{|c|c|c|c|c|}
\hline Predictors & $\begin{array}{c}(1) \\
\text { Total } \\
\text { Federal } \\
\text { Aid }\end{array}$ & $\begin{array}{c}\text { Dependent } \\
\text { (2) } \\
\text { Federal } \\
\text { Aid } \\
\text { Per Pupil }\end{array}$ & $\begin{array}{c}\text { Variable Mode } \\
(3) \\
\text { Total } \\
\text { State } \\
\text { Aid }\end{array}$ & $\begin{array}{c}(4) \\
\text { State } \\
\text { Aid } \\
\text { Per Pupil }\end{array}$ \\
\hline Enrollment & $\begin{array}{c}.62^{* *} \\
(30.14)\end{array}$ & & $\begin{array}{c}.97^{* *} \\
(1,860)\end{array}$ & \\
\hline Black \% & . & $\begin{array}{c}-.04^{* *} \\
(-64.81)\end{array}$ & & $\begin{array}{r}.02^{*} \\
(764.19)\end{array}$ \\
\hline Poor Children \% & & $\begin{array}{c}.11^{* *} \\
(603.81)\end{array}$ & & $\begin{array}{c}.00 \\
(26.39)\end{array}$ \\
\hline Income Per Cap & & $\begin{array}{l}-.06^{* *} \\
(-.00)\end{array}$ & & $\begin{array}{l}-.07^{* *} \\
(-.16)\end{array}$ \\
\hline Own Revenue/Pupil & & $\begin{array}{c}.00 \\
(.00)\end{array}$ & & $\begin{array}{l}.33^{* *} \\
(.41)\end{array}$ \\
\hline Debt Int./Pupil & & $\begin{array}{c}.00 \\
(.01)\end{array}$ & & $\begin{array}{c}.02 \\
(.66)\end{array}$ \\
\hline Intercept & $-26,697$ & 33.30 & $-1,022,343$ & $1736.37^{\prime}$ \\
\hline$\overline{\mathrm{R}}^{2}$ & .38 & .02 & .93 & .11 \\
\hline $\mathbf{N}$ & 13,654 & 13,655 & 13,654 & 13,652 \\
\hline
\end{tabular}

${ }^{*} \mathrm{p} \leq .05 \quad{ }^{* *} \mathrm{p} \leq .01$

(Figures in parentheses are unstandardized regression coefficients)

capita incomes (beta $=-.06$ ). Own source revenue and debt have no impact in this model, while the proportion of blacks in the district has a weak and inverse relationship to targeted aid. Overall, only 2 percent of the variation in per pupil federal aid is explained with this model.

Next we consider the models of state aid. Table 1 also shows the equations predicting state transfer payments using enrollment and the selected indicators of district need. If one looks first at the total dollars of state aid (column 3), the immense power of enrollment alone is obvious. Enrollment has a beta value of .97 and this model shows that enrollment accounts for 93 percent of the variation in total state aid in 1982. So in the aggregate, 93 percent of all state funds for public schools across the country can be accounted for by enrollment alone. Again, the need variables can add nothing to explaining total state aid. We also checked to see if total school population can account for variation in state dollars per pupil and found that it does not. This 
nonrelationship suggests the possibility that some targeting might be going on. The final model in column 4 tests that assumption. Indeed, school districts with higher proportions of black residents and lower per capita incomes receive more state funds per pupil. But this evidence of targeting is offset by some nontargeting relationships. Higher own source revenues per pupil is a significant determinant of per pupil aid, contrary to our expectation. Overall, the pooled analysis model accounts for 11 percent of the variation in state aid per pupil.

Questions could be raised about the analysis being sensitive to the effects of a few very large or very small school districts in the data set. Hypothetically, a few outliers could skew the results. To check this possibility, we divided the districts into four enrollment groups and used model three (Table 1) to determine if state targeting might vary by district size. In general, the pooled analysis shows that targeting is better in larger districts. ${ }^{7}$

As suggested above, some state educational funding systems may be much less enrollment-driven than others. If so, a pooled analysis may be subject to the effects produced by just a few good or poor targeting states. To investigate this possibility, we performed separate regressions for each state, treating the school districts of each state as part of a system with its own unique distribution characteristics. We initially assessed the linkage between a state's total aid to schools and district enrollment for the 44 states delineated above. The regression results showed that in 28 of the 44 states, total aid was allocated nearly exclusively on the basis of enrollment. In these states ${ }^{8}$ nearly all state education funding (98 to 99 percent) was based on enrollment. Another six states (KS, MI, NM, NY, OH, SD) allocated 90 to 97 percent of aid on that basis. School aid in the remaining 10 states (CT, ME, MA, MO, MT, NH, NJ, TN, VT, WY), many found in the Northeast, was somewhat less predicted by enrollment alone (70 to 89 per-

${ }^{7}$ The model accounts for just 12 percent of variance for districts of less than 1,000 students but reaches 32 percent for the largest jurisdictions. In three larger enrollment groups $(1,000-4,999,5,000-9,999,10,000+$ students $)$ proper targeting is apparent to districts with lower own source funds, higher proportions of children from poor families, and higher debt burdens per pupil. The relative size of the black population in these districts has little or no effect in the models. And the smallest schools (less than 1,000) reflect only one weak targeted relationship (income). Regression models for federal aid per pupil with the five predictors across the four enrollment categories generally showed little difference.

${ }^{8}$ The states included AL, AZ, AR, CA, CO, DE, FL, GA, ID, IL, IN, IA, KY, LA, MS, NE, NV, NM, ND, OK, OR, PA, SC, TX, UT, WA, WV, WI. 
cent). The 16 states that do not allocate aid exclusively on the basis of district enrollment are worth more detailed study.

As the final step, we conduct a within state analysis for the 16 "better" targeting states, using per pupil aid as the dependent variable. The results of this exercise appear in Table 2. The multiple regression equations reveal that among these states, a few represent good fits to our model. The explained variance ranges from a low of 0 percent for Tennessee to a high of 98 percent in Montana. (The Montana results are almost exclusively attributable to one nontargeted predictor, own source revenue, and as such it is clearly a deviant case). Perhaps more important than the overall predictive capacity of the model is the variability among the states in their response to need variables.

None of the states react to all five indicators of need. Maine and New York are the most responsive states, with significant targeting relationships for four of the five predictors. In each of these states, the only nonsignificant predictor is proportion of poor children, although it is in the targeted direction. Excluding Montana, we find that Maine and New York stand out as the best targeting states with explained variances of 45 and 49 percent, respectively. Four states-Michigan, Missouri, New Jersey, and Ohio-respond to three indicators of need. Each is somewhat special in its targeting predictors, although the range of explained variance is similar (21 to 37 percent). Four more - Kansas, Massachusetts, Montana, and Vermont - concentrate on just two measures of need. Minnesota, New Hampshire, South Dakota, and Wyoming show significant targeting relationships with one need indicator, while Connecticut and Tennessee target none of our measures. And what of socioeconomic versus fiscal targeting by these states? While 10 states respond significantly to socioeconomic indicators (i.e., blacks, poor children, income), 11 states target fiscal need (i.e., lower revenues, higher debt). We might note, though, that unlike the case for the social or economic measures, several of the significant fiscal variables are in the wrong direction (for own revenue-Minnesota, Montana; for debt - South Dakota). ${ }^{9}$ Only five states target to greater minority population; four of these have sizable black populations. And only four states provide proportionately more funding to districts with higher

\footnotetext{
${ }^{9}$ In these two anomalous states, Minnesota and Montana, districts that raise larger sums of money on their own are rewarded with more state funding. This arrangement bears a resemblance to the funding formula for the now defunct federal General Revenue Sharing program, which included tax effort as one of its three equally-weighted components.
} 
TABLE 2

Regression Models for State Aid Per Pupil to Independent School

Districts for 16 Better TARgeting States, 1982A

\begin{tabular}{|c|c|c|c|c|c|c|c|}
\hline State & $\overline{\mathrm{R}}^{2}$ & $\begin{array}{l}\text { Percent } \\
\text { Black }\end{array}$ & $\begin{array}{l}\text { Pct Poor } \\
\text { Children }\end{array}$ & $\begin{array}{l}\text { PerCap } \\
\text { Income }\end{array}$ & $\begin{array}{c}\text { Own Revenue } \\
\text { Per Pupil }\end{array}$ & $\begin{array}{l}\text { Debt Interest } \\
\text { Per Pupil }\end{array}$ & Intercept \\
\hline Connect. & .30 & $\begin{array}{c}.13 \\
(4310.13)\end{array}$ & $\begin{array}{r}.64 \\
(12126.08)\end{array}$ & $\begin{array}{c}.09 \\
(.01)\end{array}$ & $\begin{array}{c}.28 \\
(.08)\end{array}$ & $\begin{array}{l}-.20 \\
(-.26)\end{array}$ & -72.15 \\
\hline Kansas & .64 & $\begin{array}{c}-.03 \\
(-464.22)\end{array}$ & $\begin{array}{c}-.03 \\
(-1053.05)\end{array}$ & $\begin{array}{l}-.08 \\
(-.04)\end{array}$ & $\begin{array}{l}-.80^{* *} \\
(-.33)\end{array}$ & $\begin{array}{l}.16^{* *} \\
(.97)\end{array}$ & 2108.83 \\
\hline Maine & .45 & $(76871.64)$ & $\begin{array}{r}.12 \\
(3544.25)\end{array}$ & $\begin{array}{l}-.27^{*} \\
(-.14)\end{array}$ & $\begin{array}{l}-.36^{* *} \\
(-.29)\end{array}$ & $\begin{array}{l}.23^{* *} \\
(.83)\end{array}$ & 2010.75 \\
\hline Mass. & .06 & $\begin{array}{c}.13 \\
(6772.31)\end{array}$ & $\begin{array}{c}.13 \\
(7069.54)\end{array}$ & $\begin{array}{l}.33 \\
(.09)\end{array}$ & $\begin{array}{l}-.42^{*} \\
(-.23)\end{array}$ & $\begin{array}{r}.32^{*} \\
(2.21)\end{array}$ & 786.79 \\
\hline Michigan & .35 & $\begin{array}{r}.24^{* *} \\
(1166.31)\end{array}$ & $\begin{array}{r}.07 \\
(1815.00)\end{array}$ & $\begin{array}{l}-.04 \\
(-.01)\end{array}$ & $\begin{array}{l}-.51^{* *} \\
(-.24)\end{array}$ & $\begin{array}{c}.07^{*} \\
(.37)\end{array}$ & 1057.72 \\
\hline Minnesota & .28 & $\begin{array}{r}-.02 \\
(-4953.90)\end{array}$ & $\begin{array}{c}.05 \\
(2745.98)\end{array}$ & $\begin{array}{l}-.05 \\
(-.04)\end{array}$ & $\begin{array}{l}.44^{* *} \\
(.76)\end{array}$ & $\begin{array}{l}.20^{* *} \\
(2.24)\end{array}$ & 1391.92 \\
\hline Missouri & .21 & $\begin{array}{r}-.03 \\
(-140.97)\end{array}$ & $\begin{array}{r}.09 * \\
(1506.44)\end{array}$ & $\begin{array}{l}-.29^{* *} \\
(-.08)\end{array}$ & $\begin{array}{l}-.16^{* *} \\
(-.09)\end{array}$ & $\begin{array}{l}-.08 \\
(-.70)\end{array}$ & 1704.89 \\
\hline Montana & .98 & $\begin{array}{r}.01 \\
(31550.13)\end{array}$ & $\begin{array}{r}-.02 \\
(-2510.05)\end{array}$ & $\begin{array}{l}-.03^{* *} \\
(-.21)\end{array}$ & $\begin{array}{l}.95^{* *} \\
(.47)\end{array}$ & $\begin{array}{r}.04^{*} \\
(1.50)\end{array}$ & 1344.06 \\
\hline New Hamp. & .04 & $\begin{array}{c}-.03 \\
(-680.51)\end{array}$ & $\begin{array}{r}.17^{*} \\
(1723.65)\end{array}$ & $\begin{array}{l}-.17 \\
(-.02)\end{array}$ & $\begin{array}{l}.06 \\
.01\end{array}$ & $\begin{array}{l}.06 \\
.07\end{array}$ & 319.52 \\
\hline New Jersey & .37 & $\begin{array}{r}.20^{* *} \\
(1352.75)\end{array}$ & $\begin{array}{c}.27^{* *} \\
(12394.00)\end{array}$ & $\begin{array}{l}-.36^{* *} \\
(-.09)\end{array}$ & $\begin{array}{l}.24^{* *} \\
(.09)\end{array}$ & $\begin{array}{l}-.04 \\
(-.24)\end{array}$ & 1333.95 \\
\hline
\end{tabular}




\begin{tabular}{|c|c|c|c|c|c|c|c|}
\hline New York & .49 & )$^{* *}$ & $\begin{array}{l}.07 .06 \\
(477.85)\end{array}$ & $(2115.70)^{* *}$ & $\begin{array}{l}-.30^{* *} \\
(-.06)\end{array}$ & $\begin{array}{l}-.49^{* *} \\
(-.11)^{\circ}\end{array}$ & $\begin{array}{l}.21 \\
(1.102300 .02\end{array}$ \\
\hline Ohio & & ) & $(736.77)$ & $(3202.50)$ & $(-.01)$ & $(-.12)$ & $(.191146 .70$ \\
\hline S. Dakota & & ) & $(-2698.84)$ & $(1081.55)$ & $(-.16)$ & $(.18)$ & $(-1.491629 .77$ \\
\hline \multirow[t]{2}{*}{ Tenn. } & .00 & .16 & -.23 & -.41 & .15 & -.03 & \\
\hline & & ) & $(289.44)$ & $(-1897.17)$ & $(-.08)$ & $(.10)$ & $(-.161224 .50$ \\
\hline \multirow[t]{2}{*}{ Wyoming } & .45 & .05 & .23 & -.17 & $* *$ & $-.58-.07$ & \\
\hline & & ) & $(12290.62)$ & (15065.63) & $(-.20)$ & $(-.41)$ & $(-.434268 .28$ \\
\hline
\end{tabular}

${ }^{*} \mathrm{p} \leq .05$

${ }^{* *} \mathrm{p} \leq .01$

aStandardized coefficients shown on first line for each state; unstandardized regression coefficients are displayed in parentheses on the second line. 
percentages of poor families with children. In sum, better targeting than expected is found among these 16 states, but more effort goes to meet the needs of economically or fiscally strapped districts than to those with greater social need. But in general we confirm our expectation that the apparent targeting of school aid among all states is substantially affected by the actions of a handful of better targeting systems.

\section{Conclusion}

This research shows that federal and state total dollar allocations to public schools are prominently affected by enrollments, especially state aid. When intergovernmental school allocations are converted to per capita amounts, however, the effect of enrollment vanishes. Still, the analysis shows that neither government engages in much targeting to the social, economic, or fiscal needs of recipient districts. What then are we to make of the various theories about how political systems allocate aid dollars? One prominent position in the economics literature suggests that if any redistribution is to occur in a decentralized political system, it must come from the central government. Yet, contrary to our expectations, we found little evidence of federal targeting of school funds. With the data available, we are unable to offer any reasonable explanation for the allocation of the federal education dollar. Another well-accepted theoretical perspective indicates that little targeting of intergovernmental aid is likely because the "law of political dispersion" compels lawmakers to spread funds as widely as possible.

This research cannot definitively confirm either of these differing viewpoints regarding how aid is allocated. For education grants, especially those from the state, enrollment remains the dominant factor in allocation formulas. Is this sufficient to accept the argument that most school aid is driven by universalistic allocation practices? We think the answer is yes. Aggregate data preclude a knowledge of decision-maker motives. But when dollars closely track people, universalism seems the most plausible explanation. Yet, when we examined state aid more closely by considering individual states separately, a somewhat different picture appeared. Some 16 states did seem to direct some of their school aid to needy districts.

What makes these states good targeters? Could it be that they have crafted educational funding systems emphasizing equalization? Not necessarily. In 1982, seven of these states funded most basic school programs through an equalization formula. But the other nine states 
used a foundation or general aid appropriation for the bulk of public school assistance. Interviews with state school finance officials in six of the best targeting states (from Table 2), ${ }^{10}$ revealed that in most cases considerable targeting was intended by the states' distribution formulas. For example, Maine considers a school district's fiscal capacity in its foundation program formula and awards aid inversely to districts' real property values. Maine also subsidizes debt service-one of the few states to consider a local district's ability to pay debt. Michigan's formula provides that most state aid is to be distributed inversely to local revenue effort and property wealth. Districts with high mileage rates and low property values will receive more funding. Missouri is one of the few states to target aid to needy children rather than needy districts. Although its formula tends to reward wealthy districts with larger numbers of children, the distribution system does require an additional appropriation of state aid for each AFDC child in a district. Until 1990 reforms, New Jersey used an equalization program designed to award more money to schools with lower equalized property values. New York's system is pulled by the demands of the New York City schools, but 60 percent of state operating aid is distributed inversely to district wealth. Among our top six targeters, only Ohio appears to be passive in providing more aid to needier schools. The state's formula is designed to give more aid to larger, urban districts. Therefore, it is likely that the states' targeting effectiveness is an artifact of larger districts, which clearly have more needy children and less wealthy property values, receiving most of the aid from state government.

The interview data essentially confirm the statistical results. The better targeting states are those with a legal plan to distribute more money to needier school districts or to districts with larger numbers of needy children. Perhaps other states could examine the distribution system in Maine or Michigan or even New York and find effective strategies for enhanced targeting capacity. Although such schemes may not always be popular politically, a few states are setting an example of good targeting both for other states and for the national government in the area of public school assistance.

${ }^{10}$ State school finance or school administration officials in Maine, Michigan, Missouri, New York, New Jersey, and Ohio were interviewed by telephone in July 1991. Reports from several of these states were also examined to understand a state's distribution system. 


\section{REFERENCES}

Advisory Commission on Intergovernmental Relations. 1980. Recent Trends in Federal and State Aid to Local Governments. Washington, DC: ACIR, July. Anagnoson, J. Theodore. 1980. "Targeting Federal Categorical Grants: An Impossible Dream?" In Helen M. Ingram and Dean Mann, eds., Why Policies Succeed or Fail. Beverly Hills, CA: Sage.

Anton, Thomas J., Jerry Cawley, and Kevin Kramer. 1980. Moving Money. Cambridge, MA: Oelgeschlager, Gunn, and Hain.

Copeland, Gary W., and Kenneth J. Meier. 1984. "Pass the Biscuits, Pappy: Congressional Decision Making and Federal Grants." American Politics Quarterly 12 (January): 3-21.

David, Stephen, and"Paul Kantor. 1983. "Urban Policy in the Federal System: A Reconceptualization of Federalism." Polity 16 (Winter): 284-303.

Downs, Anthony. 1980. "Using the Lessons of Experience to Allocate Resources in the Community Development Program." In Jon Pynoos, Robert Schafer, and Chester Hartman, eds., Housing Urban America. New York: Aldine.

Dye, Thomas R., and Thomas L. Hurley. 1978. "The Responsiveness of Federal and State Governments to Urban Problems." Journal of Politics 40 (February): 196-207.

_ 1981. "Measuring Responsiveness: A Brief Reply." Journal of Politics 43 (February): 102-3.

Fuhrman, Susan. 1982. "State-Level Politics and School Financing." In Nelda Cambron-McCabe and Allan Odden, eds., The Changing Politics of School Finance. Cambridge, MA: Ballinger.

Ladd, Helen F., and Fred C. Doolittle. 1982. "Which Level of Government Should Assist the Poor?" National Tax Journal 35 (September): 323-26.

Morgan, David R., and John P. Pelissero. 1989. "Interstate Variation in the Allocation of State Aid to Schools." Publius: The Journal of Federalism 19 (Spring): 113-26.

Oates, Wallace F. 1972. Fiscal Federalism. New York: Harcourt, Brace, and Jovanovich.

Pelissero, John P. 1984. "State Aid and City Needs: An Examination of Residual Aid to Large Cities." Journal of Politics 46 (August): 916-35.

_ 1985. "Welfare and Education Aid to Cities: An Analysis of State Responsiveness to Needs." Social Science Quarterly 66 (June): 444-52.

Pelissero, John P., and David Morgan. 1987. "State Aid to Public Schools: An Analysis of State Responsiveness to School District Needs." Social Science Quarterly 68 (September): 466-77.

Peterson, Paul E. 1981. City Limits. Chicago, IL: University of Chicago Press.

Rafter, David O. 1985. "Implementing Urban Housing Rehabilitation Programs: A Comparison of the Federal and State Experiences." Journal of Urban Affairs 7 (Spring): 47-64.

Rich, Michael J. 1982. "Hitting the Target: The Distributional Impacts of the Urban Development Action Grant Program." Urban Affairs Quarterly 17 (March): 285-301. 
Stein, Robert M. 1981. "The Targeting of State Aid: A Comparison of Grant Delivery Systems." Urban Interest (Special Issue): 47-60.

—_ and Keith E. Hamm. 1987. "A Comparative Analysis of the Targeting Capacity of State and Federal Intergovernmental Aid Allocations: 1977-1982." Social Science Quarterly 68 (September): 447-65.

Stephens, G. Ross, and Gerald W. Olson. 1981. "The Redistributive Function of Federal and State Governments." Urban Interest 3 (Special Issue): 33-46.

Timpane, Michael. 1978. "Federal Aid to Education: Prologue and Prospect." In M. Timpane, ed., The Federal Interest in Financing Schooling. Cambridge, MA: Ballinger.

Tsang, Mun, and Henry M. Levin. 1983. "The Impact of Intergovernmental Grants on Educational Expenditure." Review of Educational Research 53 (Fall): 329-67.

U.S. Bureau of the Census. 1990. Government Finances in 1987-88. Washington, DC: Government Printing Office.

- 1983. 1982 Census of Governments, Vol. 1, Governmental Organization. Washington, DC: Government Printing Office, Table 11.

U.S. General Accounting Office. 1990. Communities in Fiscal Distress: State Grant Targeting Provides Limited Help. Washington, DC: April.

Ward, Peter D. 1981. "The Measurement of Federal and State Responsiveness to Urban Problems." Journal of Politics 43 (February): 83-101.

Warren, Charles R. 1981. "Targeting of State Assistance: Opportunities and Realities." The Urban Interest 3 (Special Issue): 21-32. 


\section{三 NOTICE OF CORRECTION}

Due to an error on page 995 in the December 1992 issue of the Western Political Quarterly (Volume 45), we are reprinting Table 2 from the article, "Targeting Intergovernmental aid to Local Schools: An Analysis of Federal and State Efforts" by John P. Pelissero and David R. Morgan. We regret the error. The correct version of the table appears on the following two pages.

\section{三 Statement of Ownership, Management and Circulation}

(REQuired by 39 U.S.C. 3685)

1. Title of publication: The POLITICAL RESEARCH QUARTERLY, formerly Western Political Quarterly. 2. October 1, 1993. 3. Frequency of issue: Quarterly. A. Number of issues published annually: 4. B. Annual Subscription Price: $\$ 35.00$. 4. Location of known office of publication: 252 Orson Spencer Hall, University of Utah, Salt Lake City, Salt Lake County, Utah 84112. 5. Location of the headquarters or general business offices of the publishers: Same. 6. Names and addresses of publisher, editor, and managing editor: Publisher, University of Utah, Salt Lake City, Utah 84112. Editor, Walter J. Stone, Department of Political Science, University of Colorado, Campus Box 333 , Boulder, CO 80309. Managing Editor, Donald W. Hanson, 252 Orson Spencer Hall, University of Utah, Salt Lake City, Utah 84112. 7. Owner: University of Utah. 8. Known bondholders, mortgages, and other security holders owning of holding 1 percent of more of the total amount of bonds, mortgages or other securities: None. 9. The purpose, function, and nonprofit status of this organization and the exempt status for federal income tax purposes: Have not changed during preceding 12 months. 10. A. Total number of copies printed (net press run): Average number of copies each issue during preceding 12 months, 2,443; single issue nearest to filing date, 2,651. B. Paid circulation: (1) Sales through dealers and carriers, street vendors, and counter sales: None. (2) Mail subscriptions: Average number of copies each issue during preceding 12 months, 2,230; single issue nearest to filing date, 2,248. C. Total paid circulation: Average number of copies each issue during preceding 12, months, 2,230; single issue nearest to filing date, 2,248. D. Free distribution by mail, carrier or other means: Average number of copies each issue during preceding 12 months, None; single issue nearest to filing date, None. E. Total distribution: Average number of copies each issue during preceding 12 months, 2,330; single issue nearest to filing date, 2,248. F. Copies not distributed: (1) Office use, left over, unaccounted, spoiled: Average number of copies each issue during preceding 12 months, 213; single issue nearest to filing date, 403. (2) Returns from news agents: None. I certify that the statements made by me above are correct and complete. Donald W. Hanson, Managing Editor, Political Research Quarterly. 
TABLE 2

Regression Models for State Aid Per Pupil to Independent School Districts for 16 Better Targeting States, 1982 a

\begin{tabular}{|c|c|c|c|c|c|c|c|}
\hline State & $\overline{\mathrm{R}^{2}}$ & $\begin{array}{l}\text { Percent } \\
\text { Black }\end{array}$ & $\begin{array}{l}\text { Percent Poor } \\
\text { Children }\end{array}$ & $\begin{array}{l}\text { PerCap } \\
\text { Income }\end{array}$ & $\begin{array}{c}\text { Own Revenue } \\
\text { Per Pupil }\end{array}$ & $\begin{array}{l}\text { Debt Interest } \\
\text { Per Pupil }\end{array}$ & Intercept \\
\hline Connect. & .30 & $\begin{array}{c}.13 \\
(4310.13)\end{array}$ & $\begin{array}{r}.64 \\
(12126.08)\end{array}$ & $\begin{array}{c}.09 \\
(.01)\end{array}$ & $\begin{array}{r}.28 \\
(.08)\end{array}$ & $\begin{array}{l}-.20 \\
(-.26)\end{array}$ & -72.15 \\
\hline Kansas & .64 & $\begin{array}{c}-.03 \\
(-464.22)\end{array}$ & $\begin{array}{c}-.03 \\
(-1053.05)\end{array}$ & $\begin{array}{l}-.08 \\
(-.04)\end{array}$ & $\begin{array}{l}-.80^{* *} \\
(-.33)\end{array}$ & $\begin{array}{l}.16^{* *} \\
(.97)\end{array}$ & 2108.83 \\
\hline Maine & .45 & $\begin{array}{r}.24^{*} \\
(76871.64)\end{array}$ & $\begin{array}{c}.12 \\
(3544.25)\end{array}$ & $\begin{array}{l}-.27^{*} \\
(-.14)\end{array}$ & $\begin{array}{l}-.36^{* *} \\
(-.29)\end{array}$ & $\begin{array}{l}.23^{* *} \\
(.83)\end{array}$ & 2010.75 \\
\hline Mass. & .06 & $\begin{array}{r}.13 \\
(6772.31)\end{array}$ & $\begin{array}{r}.13 \\
(7069.54)\end{array}$ & $\begin{array}{c}.33 \\
(.09)\end{array}$ & $\begin{array}{l}-.42^{*} \\
(-.23)\end{array}$ & $\begin{array}{r}.32^{*} \\
(2.21)\end{array}$ & 786.79 \\
\hline Michigan & .35 & $\begin{array}{r}24^{* *} \\
(1166.31)\end{array}$ & $\begin{array}{r}.07 \\
(1815.00)\end{array}$ & $\begin{array}{c}-.04 \\
(-.01)\end{array}$ & $\begin{array}{l}-.51 * * \\
(-.24)\end{array}$ & $\begin{array}{c}.07^{*} \\
(.37)\end{array}$ & 1057.72 \\
\hline Minnesota & .28 & $\begin{array}{r}-.02 \\
(-4953.90)\end{array}$ & $\begin{array}{c}.05 \\
(2745.98)\end{array}$ & $\begin{array}{l}-.05 \\
(-.04)\end{array}$ & $\begin{array}{l}.44^{* *} \\
(76)\end{array}$ & $\begin{array}{l}.20^{* *} \\
(2.24)\end{array}$ & 1391.92 \\
\hline Missouri & .21 & $\begin{array}{c}-.03 \\
(-140.97)\end{array}$ & $\begin{array}{r}.09 * \\
(1506.44)\end{array}$ & $\begin{array}{l}-.29 * * \\
(-.08)\end{array}$ & $\begin{array}{l}-.16^{* *} \\
(-.09)\end{array}$ & $\begin{array}{l}-.08 \\
(-.70)\end{array}$ & 1704.89 \\
\hline Montana & .98 & $\begin{array}{r}.01 \\
(31550.13)\end{array}$ & $\begin{array}{r}-.02 \\
(-2510.05)\end{array}$ & $\begin{array}{l}-.03 * * \\
(-.21)\end{array}$ & $\begin{array}{l}.95^{* *} \\
(.47)\end{array}$ & $\begin{array}{r}.04^{*} \\
(1.50)\end{array}$ & 1344.06 \\
\hline New Hamp. & .04 & $\begin{array}{c}-.03 \\
(-680.51)\end{array}$ & $\begin{array}{r}.17^{*} \\
(1723.65)\end{array}$ & $\begin{array}{c}-.17 \\
(-.02)\end{array}$ & $\begin{array}{l}.06 \\
.01\end{array}$ & $\begin{array}{l}.06 \\
.07\end{array}$ & 319.52 \\
\hline New Jersey & .37 & $\begin{array}{r}.20^{* *} \\
(1352.75)\end{array}$ & $\begin{array}{r}.27^{* *} \\
(12394.00)\end{array}$ & $\begin{array}{l}-.36^{* *} \\
(-.09)\end{array}$ & $\begin{array}{l}.24 * * \\
(.09)\end{array}$ & $\begin{array}{l}-.04 \\
(-.24)\end{array}$ & 1333.95 \\
\hline
\end{tabular}




\begin{tabular}{|c|c|c|c|c|c|c|c|}
\hline New York & .49 & $\begin{array}{c}.07^{* *} \\
(477.85)\end{array}$ & $\begin{array}{r}.06 \\
(2115.70)\end{array}$ & $\begin{array}{l}-.30^{* *} \\
(-.06)\end{array}$ & $\begin{array}{l}-.49 * * \\
(-.11)\end{array}$ & 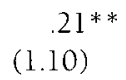 & 2300.02 \\
\hline Ohio & .21 & $\begin{array}{c}19 * * \\
(736.77)\end{array}$ & $\begin{array}{c}.14 * * \\
(3202.50)\end{array}$ & $\begin{array}{c}-.07 \\
(-.01)\end{array}$ & $\begin{array}{l}-31 * * \\
(-.12)\end{array}$ & $\begin{array}{l}.03 \\
(.19)\end{array}$ & 1146.70 \\
\hline So. Dakota & .37 & $\begin{array}{r}-.06 \\
(-2698.84)\end{array}$ & $\begin{array}{r}.11 \\
(1081.55)\end{array}$ & $\begin{array}{l}-.45^{* *} \\
(-.16)\end{array}$ & $\begin{array}{l}32 * * \\
(.18)\end{array}$ & $\begin{array}{c}-.17^{* *} \\
(-1.49)\end{array}$ & 1629.77 \\
\hline Tenn. & .00 & $\begin{array}{c}.16 \\
(289.44)\end{array}$ & $\begin{array}{c}-.23 \\
(-1897.17)\end{array}$ & $\begin{array}{l}-.41 \\
(-.08)\end{array}$ & $\begin{array}{l}.15 \\
(.10)\end{array}$ & $\begin{array}{l}-.03 \\
(-.16)\end{array}$ & 1224.50 \\
\hline Vermont & .07 & $\begin{array}{c}-.00 \\
(-529.19)\end{array}$ & $\begin{array}{c}.01 \\
(348.44)\end{array}$ & $\begin{array}{l}-.22^{* *} \\
(-.10)\end{array}$ & $\begin{array}{l}-.13^{*} \\
(-.04)\end{array}$ & $\begin{array}{l}.06 \\
(.33)\end{array}$ & 1318.54 \\
\hline Wyoming & .45 & $\begin{array}{r}.05 \\
(12290.62\end{array}$ & $\begin{array}{r}.23 \\
(15065.63)\end{array}$ & $\begin{array}{l}-.17 \\
(-.20)\end{array}$ & $\begin{array}{l}-.58^{* *} \\
(-.41)\end{array}$ & $\begin{array}{l}-.07 \\
(-.43)\end{array}$ & 4268.28 \\
\hline
\end{tabular}

$* p \leq .05$

${ }^{* *} \mathrm{p} \leq .01$

aStandardized coefficients shown on first line for each state; unstandardized regression coefficients are displayed in parentheses on the second line. 


\section{POLITICAL RESEARCH QUARTERLY}

(Formerly Western Political Quarterly)

Official journal of the Western Political Science Association, published since 1948 by the University of Utah, the Quarterly offers:

- A wide range of articles based on research in the field of political science aimed at the professional political scientist

- Four issues per year published March, June, September, December

The final issue of each volume contains an author index

- Back issues and microfilm

- Membership in the Western Political Science Association

- Low annual subscription rates:

$\$ 20.00$-individuals, $\$ 11.00$-students and retired members

$\$ 35.00$-institutions (agency discounts available)

Subscribers from Canada and Mexico add $\$ 2.50$ for postage; other foreign subscribers add $\$ 4.00$ for postage

\section{SPECIAL OFFER FOR NEW SUBSCRIBERS}

A FREE copy of

The Elusive Executive: Discovering Statistical Patterns in the Presidency by Gary King and Lyn Ragsdale

The Elusive Executive presents the most comprehensive set of data on presidents and the American Presidency ever assembled in one source. Professor King serves as the Director of the Harvard Data Center and is the author of four books, numerous articles, and several computer programs. Professor Ragsdale has written two books, many articles and recently served as the Director of the University of Arizona Survey Research Center. She is currently an Associate Professor of Political Science at the University of Arizona. FREE copies available while supply lasts; bookrate postage paid by Political Research Quarterly.

For more information about the Political Research Quarterly or to subscribe, contact: Political Research Quarterly

University of Utah

Political Science Department

252 Orson Spencer Hall

Salt Lake City, Utah 84112

USA

Phone: (801) 581-7031 FAX: (801) 585-6492 